\title{
REWITALIZACJA A ODNOWA WSI ANALIZA PORÓWNAWCZA INSTRUMENTÓW UNII EUROPEJSKIEJ ${ }^{1}$
}

Zarys treści Artykuł został poświęcony szerszemu omówieniu istoty dwóch instrumentów związanych z rozwojem wsi, finansowanych ze środków Unii Europejskiej, tj. odnowie oraz rewitalizacji wsi. Odnowa i rewitalizacja to dwa ważne instrumenty rozwoju wsi, które są współfinansowane ze środków Unii Europejskiej w ramach Wspólnej Polityki Rolnej (poprzez Program Rozwoju Obszarów Wiejskich - odnowa wsi) oraz polityki spójności (poprzez Regionalne Programy Operacyjne poszczególnych województw - rewitalizacja). W artykule dokonano charakterystyki obu podejść wraz ze wskazaniem podobieństw i różnic, które się z nimi wiążą. Ponadto udzielono odpowiedzi na pytanie, na ile każdy z instrumentów wpływa na aktywizację mieszkańców oraz uwzględnia w procesie tworzenia poszczególnych dokumentów udział różnych grup społecznych, instytucji publicznych i prywatnych itp. Obydwa podejścia - choć w założeniach podobne do siebie - nie dublują się ani nie wykluczają, ale uzupełniają się i są względem siebie komplementarne.

Słowa kluczowe Rewitalizacja, odnowa wsi, fundusze unijne, obszary wiejskie, aktywizacja mieszkańców.

\section{Wprowadzenie}

Zmiany prowadzone na obszarach wiejskich zmierzające do poprawy wiejskiej przestrzeni, ocenianej przez pryzmat ładu przestrzennego i architektonicznego, estetyki krajobrazowej oraz zachowania zasobów i form dziedzictwa materialnego, jak również do poprawy jakości życia jej mieszkańców, są coraz silniej akcentowane jako jedne z głównych kierunków w rozwoju obszarów wiejskich.

\footnotetext{
${ }^{1}$ Projekt został sfinansowany ze środków Narodowego Centrum Nauki przyznanych na podstawie decyzji numer DEC-2012/07/B/HS4/00364.
} 
Wymagają one jednocześnie znacznego wsparcia finansowego oraz zaangażowania społeczności lokalnych w proces rozwoju swojej „małej ojczyzny” i wzięcia odpowiedzialności za jej przyszłość. Odpowiedzią na powyższe problemy są programy odnowy wsi oraz rewitalizacji, które kompleksowo ujmują wspomniane aspekty.

Możliwości związane z finansowaniem przedsięwzięć w ramach obu programów na szerszą skalę pojawiły się wraz ze wstąpieniem Polski do UE i dostępem do środków pochodzących z budżetu Unii Europejskiej, które spływają na polską wieś zarówno w ramach polityki spójności (głównie Regionalne Programy Operacyjne), jak i Wspólnej Polityki Rolnej (Program Rozwoju Obszarów Wiejskich). Jako pierwsze pojawiły się działania związane z odnową wsi, które są finansowane od 2004 roku.

Od 2014 roku, równolegle do działania „Odnowa Wsi”, funkcjonuje nowy instrument finansowany ze środków UE - rewitalizacja $\mathrm{wsi}^{2}$. Pierwotnie proces rewitalizacji najczęściej odnoszono do miast, terenów zurbanizowanych, poprzemysłowych czy powojskowych. Obecnie pojęcie to stosowane jest również w odniesieniu do wsi. Jego znaczenie wzrosło wraz z pojawieniem się możliwości finansowania przedsięwzięć na wsi ze środków unijnych w ramach polityki spójności. Rozpatrując oba podejścia w rozwoju wsi z punktu stricte naukowego mamy do czynienia $\mathrm{z}$ dwoma paradygmatami, natomiast z punktu władz samorządowych, instytucji, stowarzyszeń czy mieszkańców mamy do czynienia z dwiema ścieżkami finansowania działań i inicjatyw na obszarach wiejskich.

Pojawienie się możliwości współfinansowania przedsięwzięć środkami UE wygenerowało impulsy aktywizacyjne, związane z szeroko zakrojonymi działaniami w celu pozyskania tychże środków (określenie potrzeb inwestycyjnych, przygotowanie dokumentacji aplikacyjnej, realizacja samego przedsięwzięcia). Absorpcja środków finansowych poprzedzona jest koniecznością przygotowania dokumentów strategicznych - planów odnowy miejscowości, lokalnych strategii rozwoju, programów rewitalizacji, w oparciu o które odbywa się procedura wdrażania środków UE.

Jednym z niezbędnych i kluczowych czynników powstawania ww. dokumentów jest aktywny udział mieszkańców na każdym etapie ich tworzenia - diagnoza lokalnych zasobów i występujących problemów, określenie wizji i celów rozwojowych, wskazanie kluczowych zadań niezbędnych dla poprawy jakości życia mieszkańców.

${ }^{2}$ Działanie dotyczące rewitalizacji wsi pojawiło się w programach finansowanych ze środków UE w perspektywie 2014-2020, jednakże kwestie formalno-prawne korzystania $\mathrm{z}$ tego instrumentu uregulowane zostały dopiero w 2015 roku - Wytyczne w zakresie rewitalizacji w programach operacyjnych na lata 2014-2020, Minister Infrastruktury i Rozwoju (MIiR/H 2014-2020/20(01)/07/2015) oraz Ustawa z dnia 9 października 2015 roku o rewitalizacji (Dz.U., 2015, poz. 1777, z późn. zm.). 
Głównym celem artykułu jest porównanie obu instrumentów, ich podstawowych założeń, wskazanie podobieństw i różnic wraz z uwzględnieniem roli społeczności lokalnych w kontekście partycypacji oraz wzmacniania aktywizacji mieszkańców. Podjęto próbę odpowiedzi na pytanie, na ile każdy z instrumentów uwzględnia w procesie tworzenia poszczególnych dokumentów udział mieszkańców, różnych grup społecznych, instytucji publicznych i prywatnych itp.

Artykuł przygotowano na podstawie studiów literatury, analizy dokumentów programowych Ministerstwa Rozwoju Wsi i Rolnictwa, analizy aktów prawnych (Wytyczne $w$ zakresie rewitalizacji $w$ programach operacyjnych na lata 2014-2020 oraz Ustawy z dnia 9 października 2015 roku o rewitalizacji) ${ }^{3}$, wytycznych programowych dotyczących zasad przygotowania lokalnych programów rewitalizacji w perspektywie finansowej 2014-2020 przygotowanych odrębnie przez Urząd Marszałkowski poszczególnych województw, danych pochodzących z Agencji Restrukturyzacji i Modernizacji Rolnictwa (centrala w Warszawie) oraz Banku Danych Lokalnych. Uzupełnieniem informacji pochodzących z powyższych źródeł są własne doświadczenia autorów wynikające z praktyki we współpracy z samorządami lokalnymi w ramach przygotowywania dokumentów strategicznych z zakresu programów odnowy miejscowości, lokalnych strategii rozwoju, programów rewitalizacji (dokumenty niezbędne do korzystania ze środków UE przeznaczonych na odnowę i rewitalizację wsi).

\section{Odnowa Wsi - idea i podstawowe zalożenia}

Pierwotnym paradygmatem działań prowadzonych na obszarach wiejskich była idea odnowy wsi, znana w Europie Zachodniej już od lat 60. XX wieku. Wspomniana koncepcja odnosi się do procesu obejmującego szerokie spektrum działań wpływających na poprawę jakości życia na wsi i wzrost tożsamości jej mieszkańców. Geneza ruchu odnowy wsi związana jest z krajami niemieckojęzycznymi, zaś autorem pojęcia - z języka niemieckiego zwanego Dorferneuerung (Dorf-wieś, Neuerung - odnowa) - był Walter Blah ${ }^{4}$ (1966: za Wilczyński 2003). Odnowa wsi jest procesem wielopłaszczyznowym, którą określają: warunki ekonomiczne wsi, warunki materialne mieszkańców, potrzeby pozamaterialne mieszkańców oraz tożsamość wsi. Szczególnie należy przy tej okazji zaakcentować wartość społeczności obszarów wiejskich, której zaangażowanie i potrzeby stanowią podstawę odnowy wsi. Bez osobistego zaangażowania lokalnej społeczności, biorącego się z przyjęcia odpowiedzialności za przyszłość wsi, odnowa wsi nie istnieje, a przynajmniej nie w jej rozumieniu sensu stricto.

\footnotetext{
${ }^{3}$ Ibidem.

${ }^{4}$ Termin,,Dorferneuerung”(odnowawsi) sformułowany przez Waltera Blaha pojawiłsię w 1966 roku w miesięczniku niemieckim „Agrarische Rundschau” i dotyczył metod zastosowanych w Bawarii, która pomimo wysokiego uprzemysłowienia oraz rozwoju gospodarczego, zachowała swoją własną tożsamość, kulturę lokalną i tradycję.
} 
Wieś często jest wskazywana jako miejsce o słabszym poziomie organizacji mieszkańców i kapitału społecznego (Kamiński 2008). Charakteryzuje się zazwyczaj licznymi problemami, wśród których do najważniejszych można zaliczyć: niższy poziom jakości życia wynikający ze specyfiki dominujących funkcji (rolnictwa, leśnictwa), brak alternatywnych źródeł dochodów, proces starzenia się ludności oraz procesy depopulacyjne (Przygodzka 2010). W polskich warunkach największym wyzwaniem rozwojowym przez kilka ostatnich dekad były działania modernizacyjne skupione na wyrównaniu dysproporcji pomiędzy miastem a wsią. Dotyczyło to głównie kwestii większego dostępu mieszkańców wsi do dóbr publicznych oraz podniesienia poziomu jakości życia, co było niejako cywilizacyjną koniecznością. Kierunek modernizacyjny doczekał się jednak krytyki z uwagi na jednostronny technokratyczno-funkcjonalistyczny sposób wprowadzania zmian, co w konsekwencji spowodowało szereg negatywnych zjawisk, szczególnie w przestrzeni społeczno-kulturowej, jak i przyrodniczo-krajobrazowej wsi. Jak zaznacza A. Kaleta (1992) te negatywne zjawiska przejawiające się m.in. w zaniku kontaktów towarzyskich, ,prywatyzacji” uczestnictwa w kulturze czy pogłębienia poczucia osamotnienia i izolacji społecznej, wynikały z utraty kulturowej tożsamości wsi. Nastąpiła ona za sprawą zaniku tradycyjnego „chłopskiego” stylu życia (...) i zastąpienia go strukturami normatywnymi charakterystycznymi dla miasta. Obserwowane trendy skutkowały w efekcie powstaniem ruchów odnowy wsi, która miała aktywizować mieszkańców oraz przyczynić się do harmonijnego rozwoju obszarów wiejskich, zapewniając przy tym ochronę dziedzictwa kulturowego i przyrodniczego.

W polskich realiach często wskazuje się małą aktywność i zaangażowanie społeczności lokalnych oraz działanie struktur władzy lokalnej i administracji poprzez pryzmat własnych interesów. Szansą na możliwości korzystania z dorobku europejskiego ruchu odnowy wsi jest aktywna społeczność lokalna, rozporządzająca swoimi organizacjami społecznymi dla rozwiązywania problemów, związanych z miejscem zamieszkania i życia. Władza lokalna i administracja powinny pełnić funkcję usługową (działania ukierunkowane na rzecz zaspakajania potrzeb społeczności) oraz instrumentalną w realizacji celów rozwojowych. W programie odnowy wsi szczególna rola przypada społeczności lokalnej jako podmiotu i siły napędowej zmian, które następują oddolnie z jej woli. To lokalna wspólnota mieszkańców jest czynnikiem sprawczym w procesie odnowy obszarów wiejskich, która stanowi nie tylko podmiot przemian i rozwoju, lecz jest również ich animatorem. R. Wilczyński (2010) podkreśla, że rozwój nie nastąpi tylko tam, gdzie mieszkańcy nie podejmą wysiłku, by stał się możliwy. Aktywność i poczucie odpowiedzialności za przyszłość wsi dają w zamian możliwość samorealizacji, poczucie wspólnoty, satysfakcję z uczestnictwa w tworzeniu dobra wspólnego. W odnowie wsi liczą się mieszkańcy oraz ogół ich potrzeb związanych z życiem na wsi, które obejmują cztery kluczowe obszary: 
- standard życia wyrażający się dorobkiem materialnym w postaci infrastruktury technicznej, obiektów mieszkalnych oraz będących w dyspozycji społeczności lokalnej,

- byt (warunki ekonomiczne), czyli możliwość pracy i zarobkowania oraz związanego z tym inwestowania i pozyskiwania środków przez społeczność lokalną,

- jakość życia, tj. niematerialna sfera relacji sąsiedzkich i międzyludzkich, uczestnictwa w życiu społeczności lokalnej, możliwości tworzenia i korzystania z oferty kulturalnej, edukacyjnej, wypoczynku i rekreacji oraz zaspokajania bieżących potrzeb bytowych,

- tożsamość i wartości życia wiejskiego, czyli to co w historii, dziedzictwie kulturowym i tradycji oraz specyfice życia wiejskiego identyfikuje i wyodrębnia wieś oraz jej społeczność, tworzy relacje w obrębie wspólnoty oraz związki z miejscem zamieszkania (Wilczyński 2010).

Kształtowanie przez samych mieszkańców warunków i jakości życia oraz bytu materialnego, przy jednoczesnym zachowaniu i wzmocnieniu tożsamości oraz wartości życia wiejskiego jest istotą idei odnowy wsi. W tym kontekście szczególna rola przypada lokalnym grupom działania (LGD) jako specyficznej formie partnerstwa międzysektorowego, które powołuje się w celu rozszerzenia kręgu osób i podmiotów, chcących partycypować w kształtowaniu kierunków rozwoju swojego terytorium (,małej ojczyzny”) oraz współdecydować i współuczestniczyć w realizacji podejmowanych działań. Ich istnienie ściśle powiązane jest ze Wspólnotową Inicjatywą LEADER powołaną na początku lat 90. XX wieku, która - jak zaznacza U. Budzich-Szukała (2008) - stanowiła próbę ukierunkowania metodologii i racjonalności wydatkowania środków publicznych, aby zapewnić trwały rozwój obszarów wiejskich.

\section{Odnowa Wsi jako instrument aktywizujący spoleczność lokalną}

W odniesieniu do działań związanych z odnową wsi zasadniczym czynnikiem aktywizującym i mobilizującym lokalne społeczności są środki unijne, które stanowią bodziec do podejmowania prób o ich pozyskanie, a tym samym umożliwiających zmiany zachodzące w przestrzeni wsi. Program Odnowy Wsi w perspektywie finansowej UE 2007-2013 był wdrażany poprzez Program Rozwoju Obszarów Wiejskich (PROW) i realizowano go dwutorowo, tj. poprzez oś 3 oraz oś 4 - podejście LEADER. Właśnie druga ze wspomnianych ścieżek pozwala uchwycić istotę i najtrafniej ocenić aktywność lokalnych społeczności, jako że była realizowana poprzez LGD, zatem zasadniczo zależała od bezpośredniej aktywności mieszkańców i osób zaangażowanych w działalność wspomnianych grup. W ramach osi 3 beneficjentami mogły być zaś osoby prawne, takie jak: gmina, instytucja kultury, dla której organizatorem jest jednostka samorządu terytorialnego, Kościół lub inny związek wyznaniowy, organizacja pozarządowa 
mająca status organizacji pożytku publicznego (w rozumieniu Ustawy z dnia 24 kwietnia 2003 roku o działalności pożytku publicznego i wolontariacie) $)^{5}$. Nieco upraszczając można stwierdzić, że oś 3 była bardziej ścieżką instytucjonalną, zaś oś 4 miała bardziej charakter prospołeczny.

Dla potrzeb związanych z oceną i wizualizacją aktywności lokalnej przybliżono stan wdrażania funduszy unijnych w Polsce poprzez podejście LEADER. $\mathrm{W}$ ramach wdrażania lokalnych strategii rozwoju (LSR), zatwierdzonych przez samorząd województwa, właściwe LGD miało za zadanie wybrać projekty do realizacji w ramach przyznanych środków. Działanie to miało na celu umożliwienie mieszkańcom określonego obszaru objętego LSR wykonanie przedsięwzięć $\mathrm{w}$ ramach tejże strategii. Ich wdrożenie powinno przyczynić się do poprawy jakości życia na obszarach wiejskich, m.in. poprawę stanu infrastruktury technicznej, wzrost aktywności lokalnych społeczności czy stymulowanie rozwoju przedsiębiorczości indywidualnej.

Działanie „Odnowa Wsi” realizowane w ramach osi 4 (LEADER) Programu Rozwoju Obszarów Wiejskich (PROW) 2007-2013 cieszyło się dużym zainteresowaniem wśród potencjalnych beneficjentów. Łącznie w kraju zrealizowano blisko 8 tys. projektów na łączną kwotę 1,76 mld zł, z czego $1,21 \mathrm{mld}$ zł $(68,7 \%)$ stanowiło wkład z funduszy UE (por. ryc. 1). Największy udział we wdrażaniu przedsięwzięć z programu odnowy wsi mieli beneficjenci z województw mazowieckiego (840 wniosków) i wielkopolskiego (822 wnioski).
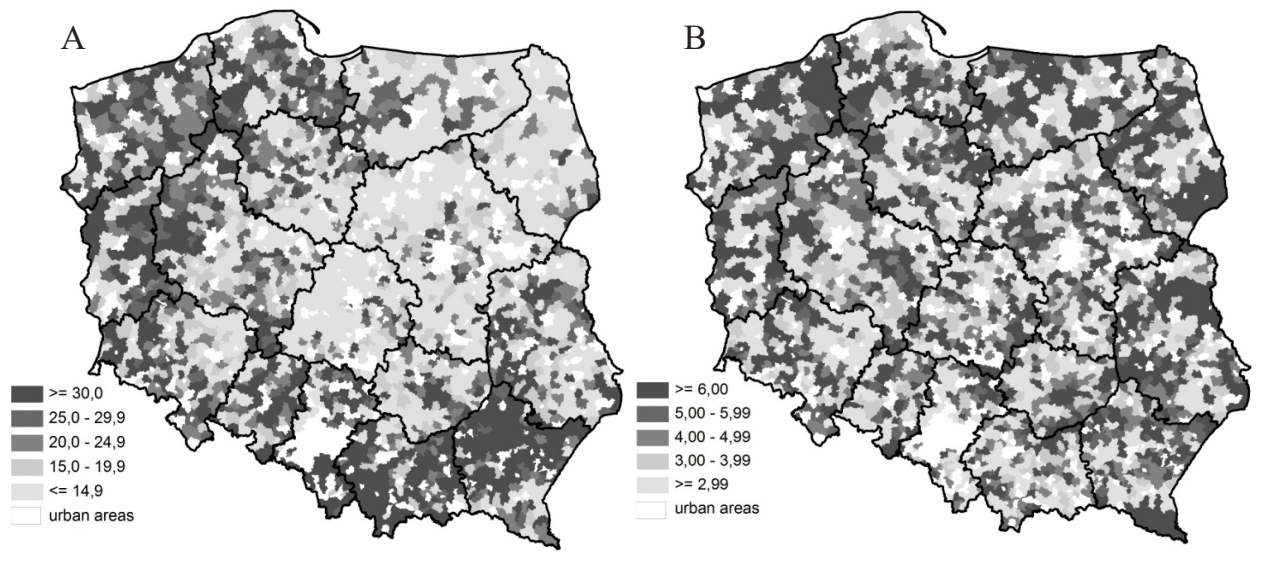

Ryc. 1. Liczba zrealizowanych projektów na: 100 miejscowości (A) oraz na 10 tys. mieszkańców (B) w Polsce w latach 2007-2013

Źródło: M. Biczkowski (2016)

${ }^{5}$ Dz.U., 2003, nr 96, poz. 873, z późn. zm. 
Najmniejszym udziałem przedsięwzięć w ich ogólnej liczbie charakteryzują się woj. opolskie (270) i lubuskie (299), co związane jest z ich niewielką wielkością, a tym samym stosunkowo małą liczbą jednostek osadniczych, potencjalnych beneficjentów (Biczkowski 2016).

Podobny rozkład efektów obserwuje się w zakresie wielkości pozyskanych środków. Jak podaje M. Biczkowski (2016), największa część funduszy z działania skierowanego na odnowę wsi trafiła do beneficjentów z woj. mazowieckiego (132,0 mln zł), małopolskiego (128,5 mln zł) i wielkopolskiego (126,8 mln zł), zaś najmniejszym udziałem cechują się woj. podlaskie (35,5 mln zł), opolskie (44,3 mln zł) i lubuskie (46,2 $\mathrm{mln} \mathrm{zł})$ - por. ryc. 2.
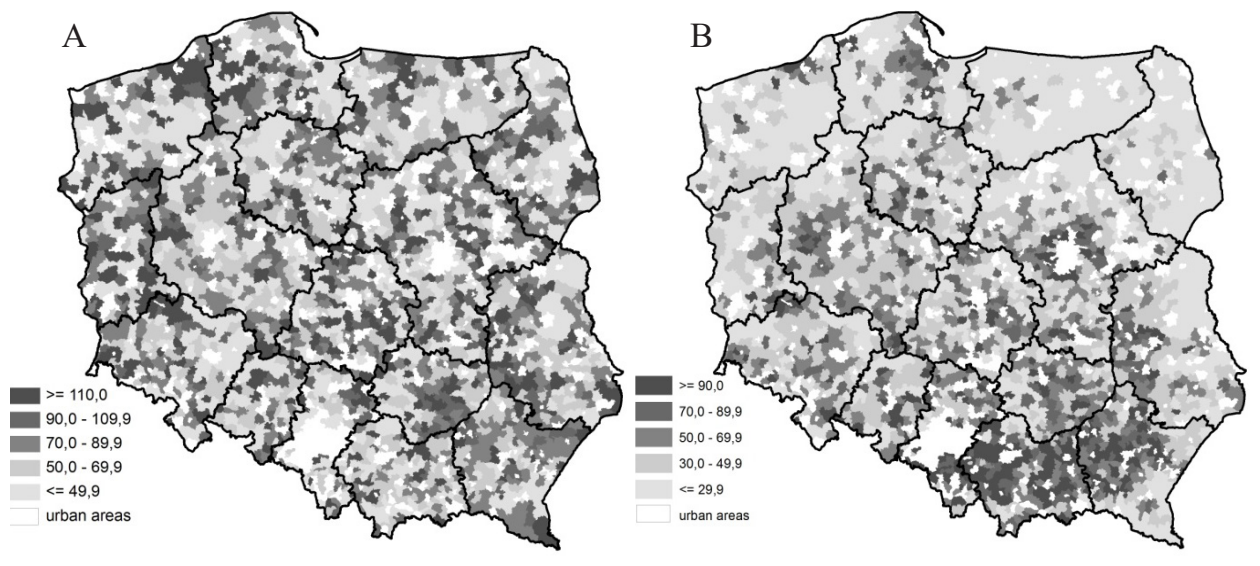

Ryc. 2. Kwota pozyskanych środków UE (w zł) na: 1 mieszkańca (A) oraz na 1 ha UR (B) w Polsce w latach 2007-2013

Źródło: M. Biczkowski (2016)

\section{Programy rewitalizacji jako narzędzia kompleksowego rozwoju obszarów wiejskich}

Zagadnienie rewitalizacji można uznać za względnie młode, gdyż rewitalizacja jest wciąż jeszcze w Polsce dziedziną in statu nascendi, która szuka swej systemowej tożsamości (Skalski 2010). Na etapie kształtowania się polityki lokalnej i regionalnej na początku XXI wieku zwrócono uwagę na konieczność kompleksowego wsparcia w zakresie rozwiązania problemów społecznych, gospodarczych, przestrzennych, środowiskowych itp. Pierwotnie proces ten z największymi sukcesami zachodził głównie w przestrzeni miejskiej i zurbanizowanej, które borykały się z problemami przestrzennymi i społeczno-gospodarczymi wynikającymi z dynamiki zjawisk rozwojowych i sytuacji rynkowej. W Polsce dotychczasowe procesy rewitalizacyjne odnosiły się głównie do ożywienia opustosza- 
łych śródmieść miast, poprawy jakości życia i odtworzenia więzi społecznych w tzw. blokowiskach czy też zagospodarowania terenów poprzemysłowych lub opuszczonych przez wojsko (Przygodzka 2010). Rewitalizacja utożsamiana jest głównie z działaniami ukierunkowanymi na aspekt infrastruktury i poprawy jakości przestrzeni publicznych w zdegradowanych ośrodkach miejskich. Zakres przedmiotowy działań rewitalizacyjnych podejmowanych na szczeblu krajowym czy regionalnym oraz wspieranych w programach rządowych obejmował przede wszystkim rewaloryzację przestrzeni zabytkowych, obiektów o istotnym znaczeniu historycznym, przestrzeni poprzemysłowych itp. (Jadach-Sepioło 2010). Doświadczenia miast Europy Zachodniej pozwoliły określić możliwe ścieżki działań rewitalizacyjnych, które docelowo mają służyć ożywieniu społecznemu i gospodarczemu w najbardziej zdegradowanych przestrzeniach (Wojnarska 2011; Kazimierczak 2014). Zakładano, że poprzez rewitalizację fizyczną wygenerowane zostaną impulsy dla rewitalizacji społecznej, a co za tym idzie osiągnięte zostaną wymierne korzyści z podejmowanych działań. Niemniej jednak w świadomości społecznej rewitalizacja utożsamiana jest nadal głównie z rewaloryzacją i renowacją (Biliński 2005; Cibis, Olejko 2005) prowadzoną głównie na terenie miejskim (Targowska 2006; Lubecka 2010). Tymczasem degradacja obszarów czy obiektów jest charakterystyczna również dla terenów wiejskich. W przestrzeni wiejskiej rewitalizacja to jednak zjawisko nowe, wynikające głównie ze zmian legislacyjnych w polskim prawie, które nastąpiły w 2015 roku. Wpłynęło to na rozwijanie (równolegle do programów odnowy wsi) lokalnych/gminnych programów rewitalizacji, poprzez które możliwe jest aplikowanie o środki na realizację przedsięwzięć z tego zakresu.

Podejście do procesów rewitalizacji ma charakter wieloaspektowy i interdyscyplinarny $\mathrm{z}$ uwagi na to, że wiąże się $\mathrm{z}$ wieloma różnorodnymi dziedzinami składającymi się na funkcjonowanie określonej jednostki administracyjnej. Dotyczy szeregu sfer, w tym: ekonomicznej, społecznej, ekologicznej, prawnej, finansowej i planistycznej. $Z$ jednej strony jest to przede wszystkim niekończący się proces dopasowywania się do społecznych i gospodarczych wewnętrznych i zewnętrznych zmian. $Z$ drugiej natomiast - choć odnowa zmierza do zachowania tradycji - jej głównym celem jest włączenie ,wartości życia wiejskiego do postępującego nurtu przemian cywilizacyjnych" (Błąd 2005).

Polska wieś dysponuje dużym potencjałem interesujących założeń przestrzennych, które często mają charakter zabytkowych układów ruralistycznych lub też zespołów dworsko-parkowych, nie zawsze wpisanych do rejestru zabytków ${ }^{6}$. To także wiele obiektów stanowiących element dziedzictwa kulturowego, wśród których są budynki gospodarcze o ciekawej architekturze, stare gorzelnie, młyny, szkoły, gościńce i zajazdy, kuźnie oraz stare zabudowania folwarczne. Potencjał tkwi również w specyfice rozłogów wsi i jej otoczenia krajobrazowego oraz

${ }^{6}$ M. Radeberg-Skorzysko (2009). 
w odniesieniu do terenów byłych państwowych gospodarstw rolnych. Powyższe miejsca odnoszą się do wartości związanych z historią, kulturą oraz tradycją - czyli wszystkim tym, co można zdefiniować jako dziedzictwo kulturowe wsi. Istotnym aspektem rozważań o rewitalizacji jest kwestia pomysłu na wieś w obecnych czasach. Rozwój świadomości społecznej na temat rewitalizacji utożsamiać można $\mathrm{z}$ procesem związanym przede wszystkim z funduszami unijnymi. Po 2007 roku w ramach szeregu programów pomocowych udostępniono pulę środków na szeroko pojęte działania rewitalizacyjne. Również obszary wiejskie w obowiązującym okresie programowania unijnego otrzymały możliwość korzystania $\mathrm{z}$ tego instrumentu, zostały bowiem uwzględnione wśród potencjalnych beneficjentów rewitalizacji. Do 2014 roku wspierane w ramach funduszy unijnych działania rewitalizacyjne dedykowane były wyłącznie ośrodkom miejskim. Dzięki zmianom legislacyjnym wprowadzonym w Ustawie o rewitalizacji z dnia 9 października 2015 roku, polskie wsie otrzymały dostęp do dodatkowej puli środków UE. Dokument ten wyznacza ramy prawne dla całego procesu rewitalizacji, porządkuje kwestie pojęciowe i proceduralne oraz ma stanowić zachętę dla samorządów do prowadzenia kompleksowego programu wyprowadzenia danego obszaru z sytuacji kryzysowej. Ustawa ma stanowić odpowiedź na brak ujednoliconych schematów działań przyczyniających się do swoistego „chaosu rewitalizacyjnego". Brak jednoznacznych, skonkretyzowanych wytycznych spowodował, że działania określane mianem rewitalizacji nie przynosiły zakładanych, społecznych efektów. Wprowadzenie ustawy otworzyło samorządom dostęp do szeregu narzędzi, które przy właściwym zastosowaniu pozwolą skoordynować i właściwie przeprowadzić proces rewitalizacji.

Ustawa określa przede wszystkim definicję rewitalizacji, która rozumiana powinna być jako ,proces wyprowadzenia ze stanu kryzysowego obszarów zdegradowanych, prowadzony w sposób kompleksowy, poprzez zintegrowane działania na rzecz lokalnej społeczności, przestrzeni i gospodarki, skoncentrowane terytorialnie, prowadzone przez interesariuszy rewitalizacji na podstawie programu rewitalizacji" (art. 2, ust. 1). Proces ten:

- powinien mieć charakter kompleksowy (tj. powinien integrować działania z zakresu różnych sfer traktując sferę społeczną jako priorytetową),

- musi wynikać bezpośrednio z potrzeb zdiagnozowanych na danym obszarze (określonych na podstawie obiektywnych wskaźników opisujących sferę społeczną, gospodarczą, przestrzenno-funkcjonalną, techniczną i środowiskową),

- powinien koncentrować się wyłącznie na obszarze rewitalizacji,

- musi opierać się na aktywnej współpracy różnych interesariuszy: podmiotów publicznych, organizacji pozarządowych, przedsiębiorców, mieszkańców itp.,

- powinien uwzględniać aktywne uczestnictwo wszystkich beneficjentów rewitalizacji (partycypacja na etapie tworzenia planu działań oraz jego monitorowania). 
Jednostka samorządowa decydująca się na koordynację działań rewitalizacyjnych w oparciu o Ustawę z dnia 9 października 2015 roku o rewitalizacji ${ }^{7}$ obligatoryjnie musi opracować tzw. Gminny Plan Rewitalizacji (GPR). Wymogi dla dokumentu zostały jasno sprecyzowane. GPR nosi jednocześnie znamiona dokumentu strategicznego, jak i wykonawczego zaplanowanych działań rewitalizacyjnych. Stosowanie Ustawy o rewitalizacji nie jest obligatoryjne. Dotyczy wyłącznie jednostek, które korzystać chcą z udogodnień, takich jak Specjalne Strefy Rewitalizacji czy miejscowy plan rewitalizacji ${ }^{8}$. Pozostałe gminy mogą prowadzić rewitalizację w oparciu o Ustawę z dnia 8 marca 1990 roku o samorządzie terytorialnym ${ }^{9}$. Niemniej, możliwość wyboru dostępna jest tylko do 31 grudnia 2023 roku. Po tym terminie jednostka decydująca się na prowadzenie rewitalizacji zobligowana będzie do stosowania wyłącznie przepisów ustawy.

Wśród dokumentów określających warunki prowadzenia rewitalizacji wymienić należy również Wytyczne w zakresie rewitalizacji w programach operacyjnych na lata $2014-2020^{10}$ oraz Wytyczne programowe dotyczace zasad przygotowania lokalnych programów rewitalizacji w perspektywie finansowej 2014-2020, które opracowywane są odrębnie w każdym województwie. Cechą wspólną powyższych dokumentów jest określenie warunków wdrażania programów operacyjnych na lata 2014-2020 w zakresie projektów realizujących cele rewitalizacji oraz wskazanie możliwości wsparcia poszczególnych przedsięwzięć wpisujących się w kata$\log$ działań wyprowadzających dany obszar z sytuacji kryzysowej. Dokumenty te - przygotowane w oparciu o Ustawę z dnia 9 października 2015 roku o rewitaliza$c j i$ - obligują jednostki do skonkretyzowania działań w postaci „Programu Rewitalizacji”, natomiast uniemożliwiają korzystanie z dodatkowych narzędzi ustawowych i prawnych. Mają one szczególnie znaczenie dla jednostek, które na działania rewitalizacyjne pragną pozyskać wsparcie w ramach dostępnych funduszy unijnych, głównie Regionalnych Programów Operacyjnych na lata 2014-2020 (RPO).

\section{Programy rewitalizacji - wyzwanie dla samorządów i mieszkańców}

Rewitalizacja, której zasady skonkretyzowane zostały w dokumentach opracowanych na szczeblu krajowym i regionalnym, stanowi obecnie duże wyzwanie dla samorządu terytorialnego. Brak jednolitych wytycznych przed 2015 rokiem

${ }^{7}$ Dz.U., 2015, poz. 1777, z późn. zm.

${ }^{8}$ Są to obszary, na których wprowadzić można szczególne regulacje i przepisy prawne umożliwiające sprawne wdrażanie programu, np. ułatwienia w realizacji celów publicznych (m.in. społeczne budownictwo czynszowe) - prawo pierwokupu przez gminę, usprawnienie procedur zamówień publicznych itp.

${ }^{9}$ Dz.U., 1990, nr 16, poz. 95, z późn. zm.

${ }^{10}$ Pierwsza wersja dokumentu przyjęta została przez Ministra Infrastruktury i Rozwoju 3 lipca 2015 roku - MIiR/H 2014-2020/20(01)/07/2015. Od sierpnia 2016 roku obowiązuje wersja zaktualizowana (MR/H 2014-2020/20(2)08/2016). 
sprawił, że znaczna część gmin opierała (a często nawet dostosowywała) swoje działania wyłącznie o wskazania wynikające z regulaminów konkursów w ramach Regionalnych Programów Operacyjnych na lata 2007-2013. W szczególnej sytuacji znalazły się obszary wiejskie, które dotychczas korzystać mogły ze wsparcia w ramach PROW oraz regionalnych programów odnowy wsi (np. Program Odnowy Wsi Województwa Opolskiego, Program Odnowa Wsi Dolnośląskiej). Dostęp do dodatkowych środków pomocowych zachęcił gminy do próby implementacji wytycznych na potrzeby rewitalizacji. Działania podejmowane na przełomie lat 2015-2016 przez jednostki samorządowe w zakresie przygotowania programów rewitalizacji wskazały na szczególne problemy i wyzwania. Do podstawowych wymienić można:

\section{Delimitacja obszaru zdegradowanego i rewitalizacji - określenie głównych problemów}

Wyznaczenie obszarów szczególnej koncentracji problemów odbywa się w oparciu o obiektywne i weryfikowalne wskaźniki. Źródłem informacji jest zarówno urząd gminy, jego jednostki organizacyjne, jak i instytucje zewnętrzne (Powiatowy Urząd Pracy, Ośrodek Pomocy Społecznej, Komenda Powiatowa Policji, Urząd Skarbowy, GUS). Dotychczasowe doświadczenia wskazały ${ }^{11}$, że obraz przestrzenny problemów zobrazowanych przez wskaźniki statystyczne nie zawsze koresponduje z subiektywnym odczuciem mieszkańców. Powstaje więc swoisty dysonans pomiędzy wskazywanymi problemami. Rozbieżność ta stanowi problem w przypadku określenia listy przedsięwzięć rewitalizacyjnych - wytyczne Ministerstwa Rozwoju wskazują, że w ramach RPO wspierane mogą być zadania, które wynikają z sytuacji kryzysowych określonych w oparciu o mierniki statystyczne.

\section{Delimitacja obszaru zdegradowanego i rewitalizacji - dostępność do danych}

Sposób agregacji danych w poszczególnych instytucjach często uniemożliwia opracowanie porównywalnych mierników dla zakładanej, stosunkowo najmniejszej, jednostki odniesienia (konkretny adres, sołectwo, osiedle).

\section{Przedsięwzięcia rewitalizacyjne - różne wytyczne w zakresie dopuszczal- nych przedsięwzięć w ramach Regionalnych Programów Operacyjnych}

W każdym z województw opracowano odrębne zasady wsparcia rewitalizacji w ramach Regionalnych Programów Operacyjnych. W przypadku ogólnych założeń są one spójne. Dotyczy to przede wszystkim określenia, że działania infrastrukturalne będą musiały stanowić wsparcie dla działań społecznych. Oznacza to, że wsparcie unijne może otrzymać wyłącznie przedsięwzięcie, które poprzez swój zakres rzeczowy przyczyni się do realizacji tzw. projektów miękkich (np. projekty mające na celu aktywizację zawodową, integrację społeczną, rozwój usług społecznych). Niemniej jednak zakres możliwych działań infra-

${ }^{11}$ Współautorka artykułu przeprowadziła kilkanaście warsztatów rewitalizacyjnych w gminach opracowujących programy rewitalizacji. 
strukturalnych zróżnicowany jest regionalnie (np. pod względem dopuszczalności przedsięwzięć w obszarze remontów dróg lokalnych).

\section{Partycypacja społeczna - oczekiwania a rzeczywistość}

We wszystkich dokumentach wyznaczających ramy prawne dla prowadzenia rewitalizacji wskazano obligatoryjne zapewnienie aktywnego udziału interesariuszy na każdym etapie prac. Dotyczy to zarówno delimitacji obszaru rewitalizacji, określenia kluczowych problemów i potrzeb rewitalizacyjnych, jak również uczestnictwa w prowadzeniu i ocenie (monitoringu) rewitalizacji. Spektrum dostępnych narzędzi partycypacyjnych, do których stosowania zobligowana jest gmina jest szeroki. Obejmuje m.in. konsultacje społeczne, ankietyzację, wywiady pogłębione, organizację spacerów studyjnych. Działania te mają dać możliwość wypowiedzenia się jak największej liczbie mieszkańców i instytucji na obszarze rewitalizacji. Dotychczasowe prace na terenie wybranych gmin (lata 2015-2016) zwróciły uwagę na coraz bardziej istotny symptom zmęczenia mieszkańców związany z konsultacjami społecznymi. W znacznej części gmin prace nad programami rewitalizacji nałożyły się na prace, a tym samym na konsultacje m.in. Planów Gospodarki Niskoemisyjnej ${ }^{12}$, Strategii Rozwoju Gminy, Planów Odnowy Miejscowości czy Lokalnych Strategii Rozwoju w ramach LGD. Zbyt duże nagromadzenie działań wymagających konsultacji i partycypacji zniechęciło część mieszkańców do uczestnictwa w kolejnych spotkaniach i ankietach.

Ponadto wyniki delimitacji obszaru rewitalizacji w oparciu o wskaźniki często nie są tożsame z wynikami delimitacji w oparciu o ocenę mieszkańców. Powoduje to spadek zainteresowania i zaangażowania mieszkańców w prace nad programem rewitalizacji. Na uwagę zasługuje fakt, że oczekiwania mieszkańców nie zawsze korespondują z rodzajem przedsięwzięć kwalifikujących się do wsparcia w ramach rewitalizacji wspartej przez fundusze unijne. Analiza potrzeb inwestycyjnych wskazuje na zdecydowaną przewagę zadań stricte infrastrukturalnych, takich jak budowa i naprawa dróg lokalnych, remont budynków użyteczności publicznych, rewitalizacja przestrzeni publicznej.

Kluczowym wyzwaniem jest zachęcenie mieszkańców do zgłaszania propozycji przedsięwzięć społecznych, dla których działania infrastrukturalne stanowić będą funkcję uzupełniającą. Interesariusze mają ponadto słabe przekonanie o szansach pozyskania wsparcia finansowego w ramach programów operacyjnych. Wynika to z formuły konkursowej oraz znacznej konkurencji w ramach poszczególnych naborów wniosków o dofinansowanie. Na etapie opracowania programu rewitalizacji potencjalni realizatorzy (organizacje pozarządowe, jednostki organizacyjne gminy, przedsiębiorcy itp.) zobligowani są do względnie szczegółowego określenia założeń proponowanych przedsięwzięć, w tym zapla-

${ }^{12}$ Dokument jest obligatoryjny w przypadku, gdy gmina zamierza aplikować o środki w ramach funduszy UE 2014-2020 na działania w obszarze gospodarki niskoemisyjnej i poprawy efektywności energetycznej. 
nowanej struktury finansowania. W gminach, w których do tej pory nie była realizowana rewitalizacja (w tym w jednostkach o przewadze obszarów wiejskich), obserwuje się tym samym mniejsze zaangażowanie podmiotów w projektowaniu procesu rewitalizacji.

\section{Rewitalizacja a Odnowa Wsi - podobieństwa i różnice w podejściu do rozwoju wsi}

W krajach europejskich zachodzące obecnie zmiany na obszarach wiejskich oparte są przede wszystkim na idei rewitalizacji, rozumianej jako nadanie starym formom i strukturom nowych funkcji adekwatnych do zmienionych potrzeb społecznych i gospodarczych. W ramach takiego procesu obiekty gospodarskie, powstałe dla potrzeb hodowli lub magazynowania płodów rolnych, mogą otrzymać „drugie życie" - przekształcają się w mieszkania, warsztaty produkcyjne, lokale usługowe oraz obiekty użyteczności publicznej ogółu mieszkańców wsi. Centra wsi stają się wiejskimi rynkami - strefami koncentracji usług, szczególnie publicznych. Bez rewitalizacji nie jest możliwe zachowanie pełni materialnego i niematerialnego zasobu kulturowego wsi. Dodatkowo ukształtowana specyfika i jakość przestrzeni publicznej wzmacniają tożsamość mieszkańców przyczyniając się do wzmocnienia całej wspólnoty.

Odnowa Wsi i rewitalizacja to dwa ważne instrumenty rozwoju wsi - różne, ale wzajemnie uzupełniające się i komplementarne. Odnowa Wsi aktywizuje poprzez ugruntowane i sprawdzone metody oraz narzędzia wspierające rozwój inicjatyw oddolnych. Odnosi się głównie do skali mikro, ma charakter bardzo lokalny, najczęściej kojarzony ze swoją „małą ojczyzną”, miejscowości w której się zamieszkuje (por. fot. 1). Rewitalizacja przyjmuje natomiast postać bardziej zinstytucjonalizowaną. Jakkolwiek również odbywa się w skali lokalnej, częściej jednak odnosi się do całej gminy, bowiem dopiero w tej skali możliwe jest porównanie poszczególnych wsi ze sobą, delimitacja oraz wydzielenie obszarów zdegradowanych, czyli miejscowości o dużej koncentracji problemów.

Mechanizmy związane z tworzeniem programów odnowy wsi oraz ich podstawowymi założeniami są już dość dobrze (w porównaniu z programami rewitalizacyjnymi) rozpoznane na gruncie polskiej wsi. Do najbardziej charakterystycznych elementów odnowy wsi jako sposobu na rozwój obszarów wiejskich, zalicza się:

- oddolność inicjatywy i zaangażowanie społeczności lokalnych,

- wykorzystywanie zasobów własnych (potencjał endogeniczny) jakimi dysponuje wieś,

- zaplanowanie rozwoju własnej wsi i dążenie do osiągnięcia ustalonej wizji i celów,

- uspołecznione planowanie rozwoju skoordynowane $\mathrm{z}$ planowaniem przestrzennym z udziałem mieszkańców,

- partycypacja-uczestnictwo mieszkańców w procesie decyzyjnym, 
- wspieranie przez gminę wiejskich inicjatyw oraz pomoc ze strony regionu,

- fachowe, instytucjonalne doradztwo ze strony specjalistów i regionu na rzecz realizacji przyjętej koncepcji rozwoju wsi.
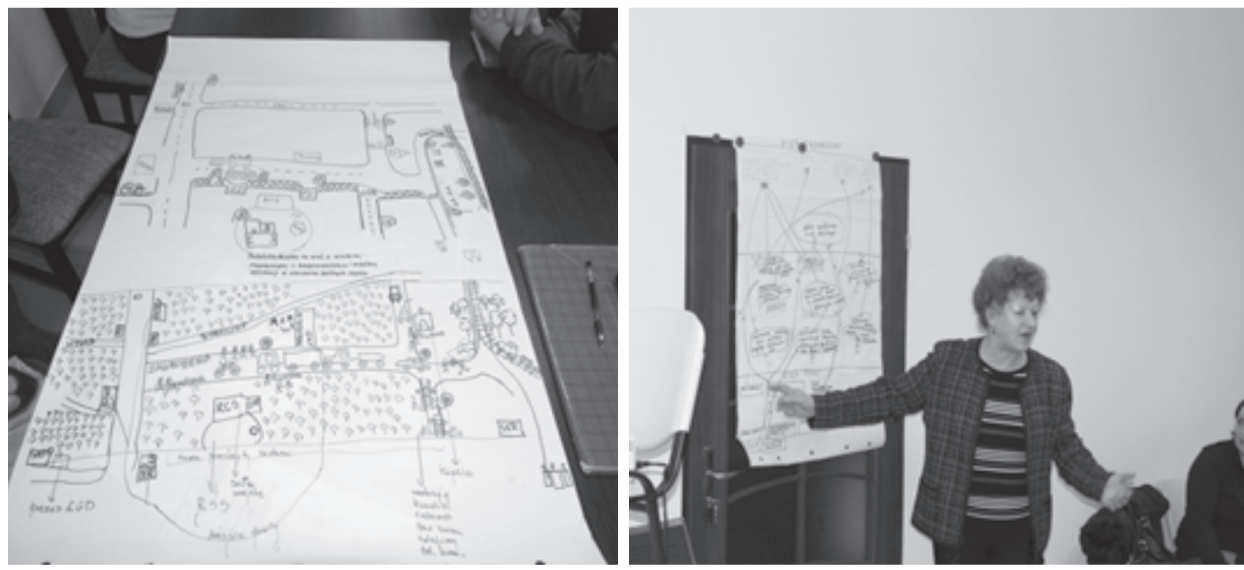

Fot. 1. Prace na sołeckimi strategiami rozwoju (SSR) w gminie Białośliwie Źródło: Sołecka Strategia Rozwoju - wsie Pobórka Wielka i Nieżychowo, gmina Białośliwie

W przypadku prac związanych z tworzeniem programów rewitalizacyjnych, do najbardziej istotnych wyróżników można zaliczyć:

- kompleksowość, tj. zsynchronizowanie działań w sferze społecznej, gospodarczej, przestrzennej, infrastrukturalnej, środowiskowej i kulturowej,

- zasadę partnerstwa polegającą na włączeniu w procesy programowania i realizacji działań rewitalizacyjnych szerokiego grona partnerów (w szczególności lokalnych społeczności, przedsiębiorców, a także innych interesariuszy procesu rewitalizacji i ekspertów),

- prowadzenie działań na wyznaczonym obszarze rewitalizacji (zdegradowanym), dotkniętym szczególną koncentracją problemów i negatywnych zjawisk kryzysowych,

- co do zasady działania realizowane są na wyznaczonym obszarze rewitalizacji (zdegradowanym), tym niemniej do objęcia wsparciem można dopuszczać projekty zlokalizowane poza tym obszarem, jeśli służą one realizacji celów zawartych w programie rewitalizacji. Zwłaszcza dotyczy to inicjatyw społecznych nakierowanych np. na aktywizację zawodową mieszkańców obszarów zdegradowanych, gdzie rozwiązania dedykowane ludności z obszaru zdegradowanego mogą być podejmowane poza obszarem zdegradowanym,

- zapewnienie komplementarności przestrzennej w celu efektywnego oddziaływania na cały dotknięty kryzysem obszar (a nie punktowo, w pojedynczych miejscach), by poszczególne przedsięwzięcia dopełniały się i zachodził między nimi efekt synergii, 
- zapewnienie komplementarności problemowej w celu przeciwdziałania fragmentacji działań (np. tzw. „rewitalizacji technicznej”, ,rewitalizacji społecznej" - określeń błędnie stosowanych, jako że rewitalizacja jest zawsze kompleksowa),

- zapewnienie komplementarności finansowej - zdolność łączenia prywatnych i publicznych źródeł finansowania, przy założeniu, że stymulowanie endogenicznych zdolności inwestycyjnych ma kluczowe znaczenie dla dynamiki pożądanych zmian,

- program rewitalizacji jest wypracowywany przez samorząd gminny i poddawany dyskusji - prace oparte są na współpracy ze wszystkimi grupami interesariuszy, w tym szczególnie z mieszkańcami obszarów rewitalizowanych, przedsiębiorcami i organizacjami pozarządowymi,

- partycypacja społeczna jest wpisana w proces rewitalizacji jako fundament działań na każdym etapie tego procesu (diagnozowanie, programowanie, wdrażanie, monitorowanie). Skonsolidowanie wysiłków różnych podmiotów na rzecz obszaru zdegradowanego jest ważnym warunkiem sukcesu.

W tabeli 1 przedstawiono główne różnice między omawianymi instrumentami rozwoju wsi - odnową a rewitalizacją.

Tabela 1

Odnowa Wsi a rewitalizacja - różnice między instrumentami

\section{ODNOWA WSI}

- sprawdzony i znany instrument wsparcia dla mieszkańców obszarów wiejskich

- duże doświadczenie we wdrażaniu działań zarówno w ramach Programu Rozwoju Obszarów Wiejskich, jak i regionalnych Programów Odnowy Wsi

- stałe wytyczne gwarantujące niezmienność zasad otrzymania wsparcia - stabilność prawa pozwala na właściwe przygotowanie przedsięwzięć

- istotna skuteczność wsparcia, 1 program - 2 osie (PROW - oś 3 oraz oś 4 - LEADER)

- znaczne zaangażowanie mieszkańców - pozytywna aktywizacja społeczności lokalnych

- projekty odnowy wsi odpowiadają realnym (a nie deklaratywnym), oddolnym, potrzebom danej społeczności lokalnej

- SSR (POM, PRW) - dokument tworzony przy dużym udziale lokalnej społeczności

\section{REWITALIZACJA}

- nowy instrument wsparcia rozwoju obszarów wiejskich

- brak doświadczenia we wdrażaniu progra$\mathrm{mu}$

- trudności i różnice interpretacyjne (na linii Urząd Marszałkowski-samorząd lokalny)

- dwie dopuszczalne ścieżki prowadzenia rewitalizacji: Ustawa o rewitalizacji oraz Wytyczne Ministerstwa Rozwoju

- Lokalny i/lub Gminny Program Rewitalizacji - LPR/GPR - dokument wymagający dużego wsparcia instytucjonalnego w celu przeprowadzenia delimitacji obszaru rewitalizacji (delimitacja obszaru + podejście ,wskaźnikowe” mocno ograniczające poziom partycypacji społecznej)

- projekty tworzone według potrzeb lokalnych instytucji oraz według odgórnych priorytetów/działań władz samorządowych - bardziej zinstytucjonalizowany instrument 


\section{Podsumowanie}

Dwa omówione w artykule i niezwykle ważne instrumenty rozwoju wsi należy postrzegać jako różne, acz uzupełniające się wzajemnie i komplementarne programy. $Z$ całą pewnością przyczyniają się one do aktywizacji społeczności lokalnych. Jest to jednakże aktywność w znacznym stopniu wymuszona procedurą tworzenia dokumentów, zakładająca konieczność udziału mieszkańców. Tym niemniej można wskazać na pewne różnice między nimi.

Jak wykazano, Odnowa Wsi posiadająca ugruntowane i sprawdzone metody oraz narzędzia wspierające rozwój inicjatyw, w większym stopniu opiera się na podejściu stricte oddolnym. Uruchamianie czynników rozwoju, w tym niematerialnych, którym przypisuje się olbrzymie znaczenie, następuje oddolnie (bottom-up) - z woli i na rzecz mieszkańców. Najczęściej zachodzi pod wpływem działania lidera/ów, którzy inicjują podjęcie określonych działań, włączając w nie mieszkańców wsi. Pomimo, iż liderzy ci najczęściej wywodzą się z lokalnych środowisk, należy podkreślić fakt, że są to osoby działające w ramach instytucji samorządowych $^{13}$. Proces pozyskiwania środków UE w większym stopniu ułatwia wsparcie instytucjonalne. Stąd działalność społeczności lokalnych wspierana jest zarówno przez poziom lokalny, jak i regionalny w formie regionalnych/wojewódzkich programów odnowy wsi.

Rewitalizacja natomiast ma natomiast formę bardziej zinstytucjonalizowaną, w której najczęściej to lokalne władze samorządowe inicjują działania w celu wypracowania programu rewitalizacji. Dopiero wtedy gdy stworzone są zręby programu jest on kierowany do partycypacji i konsultacji społecznych. W przypadku rewitalizacji również mówimy o podejściu oddolnym - wszystko odbywa się w obrębie podstawowej jednostki samorządowej jaką jest gmina - jednakże tutaj inicjatywa i zarazem rola lidera przypada władzom samorządowym, a nie mieszkańcom. W kontekście aktywizacji społeczności lokalnych właśnie ten aspekt stanowi najistotniejszą różnicę. Tym niemniej z całą pewnością należy stwierdzić, że oba podejścia pełnią ważną rolę i powinny znacząco przyczynić się do wieloaspektowego rozwoju polskiej wsi.

${ }^{13}$ Zgodnie z wynikami badań M. Biczkowskiego i R. Rudnickiego, około 90\% ogółu przedsięwzięć zrealizowanych w ramach działania „Odnowa wsi” (PROW 2007-2013) inicjowana jest przez urząd gminy (władze samorządowe) oraz jego jednostki organizacyjne (materiały konferencyjne XXXIII Seminarium Geografii Wsi, 1-2.06.2017 Tomaszowice k. Krakowa). 


\section{LITERATURA}

Biczkowski M., 2016, Fundusze unijne wdrażane poprzez Regionalne Programy Operacyjne jako neoendogeniczny czynnik rozwoju obszarów wiejskich, [w:] Heffner K., Klemens B. (red.), Studia Obszarów Wiejskich - Społeczny wymiar rozwoju obszarów wiejskich, 41, Warszawa.

Biliński T., 2005, Renowacja budynków i modernizacja obszarów zabudowanych, t. 1, Oficyna Wydawnicza Uniwersytetu Zielonogórskiego, Zielona Góra.

Błąd M., 2005, Znaczenie programów odnowy wsi w rozwoju obszarów wiejskich w Polsce, [w:] Rosner A. (red.), Uwarunkowania i kierunki przemian społeczno-gospodarczych na obszarach wiejskich, IRWiR, Warszawa.

Budzich-Szukała U., 2008, Program LEADER w Polsce - sposób na aktywizację wsi, [w:] Wilkin J., Nurzyńska I. (red.), Polska wieś 2008. Raport o stanie wsi, Fundacja na Rzecz Rozwoju Polskiego Rolnictwa, Warszawa.

Cibis J., Olejko W., 2005, Rewitalizacja istniejacych zasobów mieszkaniowych - aktualne potrzeby i możliwości realizacji, [w:] Renowacja budynków i modernizacja obszarów zabudowanych, t. 1, Zielona Góra.

Jadach-Sepioło A., 2010, Rewitalizacja miast w dokumentach strategicznych w Polsce. Odniesienie do projektu Krajowej Strategii Rozwoju Regionalnego 2010-2020: Regiony, miasta, obszary wiejskie, [w:] Skalski K. (red.), O budowie metod rewitalizacji w Polsce - aspekty wybrane, Monografie i Studia Instytutu Spraw Publicznych Uniwersytetu Jagiellońskiego, Kraków.

Kaleta A., 1992, Podstawowe założenia odnowy obszarów wiejskich Europy, [w:] Odnowa wsi - między mitem a nadzieja, IRWiR PAN, Warszawa.

Kamiński R., 2008, Aktywność społeczności wiejskich. Lokalne inicjatywy organizacji pozarzadowych. Problemy rozwoju wsi i rolnictwa, IRWiR PAN, Warszawa.

Kazimierczak J., 2014, Wpływ rewitalizacji terenów poprzemysłowych na organizację przestrzeni centralnej w Manchesterze, Lyonie i Łodzi, Wydawnictwo Uniwersytetu Łódzkiego, Łódź.

Lubecka A., 2010, Rewitalizacja/gentryfikacja jako element zmieniajacy semantyke miasta, [w:] Skalski K. (red.), O budowie metod rewitalizacji w Polsce-aspekty wybrane, Monografie i Studia Instytutu Spraw Publicznych Uniwersytetu Jagiellońskiego, Kraków.

Przygodzka R., 2010, Lokalne grupy działania a procesy rewitalizacyjne na obszarach wiejskich, [w:] Skalski K. (red.), O budowie metod rewitalizacji w Polsce - aspekty wybrane, Monografie i Studia Instytutu Spraw Publicznych Uniwersytetu Jagiellońskiego, Kraków.

Radeberg-Skorzysko M., 2009, Problemy rewitalizacji małych miast $i$ wsi. Przykłady z pogranicza województw zachodniopomorskiego i wielkopolskiego, http://www. srl.de/dateien/dokumente/de/problemy_rewitalizacji_malych_miast_i_wsi_ przyklady_z_pogranicza_wojewodztw_zachodniopomorskiego_i_wielkopolskiego.pdf (dostęp: 03.01.2017).

Skalski K. (red.), 2010, O budowie metod rewitalizacji w Polsce - aspekty wybrane, Monografie i Studia Instytutu Spraw Publicznych Uniwersytetu Jagiellońskiego, Kraków. 
Targowska F., 2006, Rewitalizacja obszarów miejskich, [w:] Projekty i programy rewitalizacji w latach 2002-2006. Studium przypadków, Kraków.

Ustawa z dnia 8 marca 1990 roku o samorzadzie terytorialnym (Dz.U., 1990, nr 16, poz. 95 , z późn. zm.).

Ustawa z dnia 24 kwietnia 2003 roku o działalności pożytku publicznego i wolontariacie (Dz.U., 2003, nr 96, poz. 873, z późn. zm.).

Ustawa z dnia 9 października 2015 roku o rewitalizacji (Dz.U., 2015, poz. 1777, z późn. zm.).

Wilczyński R., 2003, Odnowa wsi perspektywą rozwoju obszarów wiejskich w Polsce, Fundacja - Fundusz Współpracy - Program Agro-Info, Krajowe Centrum Doradztwa Rozwoju Rolnictwa i Obszarów Wiejskich, Poznań.

Wilczyński R., 2010, Jak rozwijać obszary wiejskie, Materiały z konferencji „Kościoły i związki wyznaniowe w „Odnowie i rozwoju wsi” PROW 2007-2013 - Partner w rozwoju obszarów wiejskich", 4-5 października 2010 r., Ośrodek Szkoleniowo-Rehabilitacyjny w Teresinie, http://ksow.pl/news/entry/1095-koscioly-i-zwiazki-wyznaniowe-w-odnowie-i.html (dostęp: 03.01.2017).

Wojnarska A., 2011, Rewitalizacja zdegradowanych obszarów miejskich. Przykłady praktyczne, Wydawnictwo Uniwersytetu Łódzkiego, Łódź.

Wytyczne $w$ zakresie rewitalizacji $w$ programach operacyjnych na lata 2014-2020, Ministerstwo Rozwoju (MR/H 2014-2020/20(2)08/2016).

Wytyczne programowe dotyczace zasad przygotowania lokalnych programów rewitalizacji w perspektywie finansowej 2014-2020, opracowane indywidualnie dla każdego z województw opracowywane przez właściwe Urzędy Marszałkowskie.

\section{REVITALIZATION OF RURAL RENEWAL COMPARATIVE ANALYSIS OF EUROPEAN UNION INSTRUMENTS}

Abstract The article was devoted to a broader discussion of the substance of two rural development instruments financed by the European Union - renewal and revitalization of rural areas.

Renewal and revitalization of rural areas are two important instruments for rural development, co-financed by the European Union under the Common Agricultural Policy (through the rural development program - rural renewal) and cohesion policy (through regional operational programs of individual voivodeships - revitalization).

The article describes the features of both approaches, together with an indication of the similarities and differences that are associated with them. In addition, the answer to the question is how much each instrument influences the activation of the population and takes into account in the process of creating individual documents the participation of different social groups, public and private institutions, etc. Both approaches, though similar in purpose, do not duplicate or exclude, but Complementary and complementary. 
Keywords Revitalization, village renewal, EU funds, rural areas, activation residents.

Dr Mirosław Biczkowski

Katedra Gospodarki Przestrzennej i Turyzmu

Wydział Nauk o Ziemi

Uniwersytet Mikołaja Kopernika w Toruniu

e-mail: mirbicz@umk.pl

Dr Marta Biczkowska

Dolnośląskie Centrum Rozwoju Lokalnego e-mail: biczkowska.marta@gmail.com 